\title{
The role of historical fishpond systems during recent flood events
}

\author{
Richard LHOTSKÝ
}

ENKI, o.p.s., Dukelská 145, CZ-379 01 Třeboň, Czech Republic

\begin{abstract}
Most of the large pond systems in the Czech Republic were built in 16th century. One of the most important fishpond systems is the one of the Třeboň basin (Třeboň fishpond system - TFS). It is situated in South Bohemia in the upper Lužnice watershed, but the whole system also includes the upper watershed in Austria. The system consists of almost 1000 fishponds with a total area of 7500 ha. Retention capacity of fishponds is estimated to be as big as $50-70 \mathrm{mil}^{3} \mathrm{~m}^{3}$, but might be even 110-140 mil. $\mathrm{m}^{3}$ during extreme floods. The situation is then often beyond control and damage occurs, which deteriorates the fishponds' water management function. The largest is Rožmberk fishpond (480 ha), which stored $50-70$ mil. $\mathrm{m}^{3}$ during the 2002 flood while its normal volume is about 5.5 mil. $\mathrm{m}^{3}$.

In order to ensure a satisfactory flood retention capacity of fishpond systems, proper maintenance of their technical equipment is necessary and emergency measures for the whole system should be added.
\end{abstract}

Key words: Czech Republic, fishponds, flood protection, water retention

\section{INTRODUCTION}

Fields, meadows, forests and ponds represent the fundamental components of the Czech landscape. The sophisticated and elaborate systems of fishponds in the Czech Republic, which have evolved through five centuries of landscape management, are quite unique. Although the pond systems are man-made, thanks to sensible landscaping throughout centuries they have fused with the surrounding nature and this synthesis has many times created valuable biotopes which are nowadays the objects of national and international protection. The pond system of the Třebon basin with its area of 7500 ha produces annually $2900 \mathrm{t}$ of fish, mainly carps, and the company managing these ponds is one of the biggest producers of freshwater fish in Europe. The ponds being an opened part of the landscape linked to streams and rivers are affected by floods and contribute to water retention of the landscape. It is a task for people of many professions to manage the half-millennium old fish- 
ponds and their systems so that they could maintain their multifunctional role in landscape, contribute to the reduction of flood waves, enhance biodiversity, remain beautiful to look at and give work to local population.

To describe the role of historical fishponds during flood events with respect to their economical importance is the purpose of this work. Fishpond landscape is man made landscape with important level of biological and landscape protection and high aesthetical value.

\section{METHODS, DATA AND INFORMATION SOURCES}

Before the 1920s the fishponds of the Třeboň (Fig. 1 and 2) basin were owned by the family of Schwarzenberg. This owner also founded an archive, today State regional archives, which is a valuable source of information about individual ponds and past events (such as flood events, dam damage etc.). It was this information source that enabled Josef Šusta to write a unique historical monography "500 years of fishpond management in the Třeboň area“. Josef Šusta was a stewart of the fishponds belonging to the Třeboň estate and his work contributed to significant improvement of fish production. He laid the foundations of modern European fishery (ŠUSTA, 1997).

The existing parameters of ponds have been obtained from water management operational guidelines, which were kindly provided by the Třeboň Fishery (Rybáŕství Třeboň, a.s.). Information about floods of 2002 and 2006 has been obtained from publicly accessible data of the Czech hydrometeorological institute and data from the state enterprise Povodí Vltavy, administrator of important watercourses,

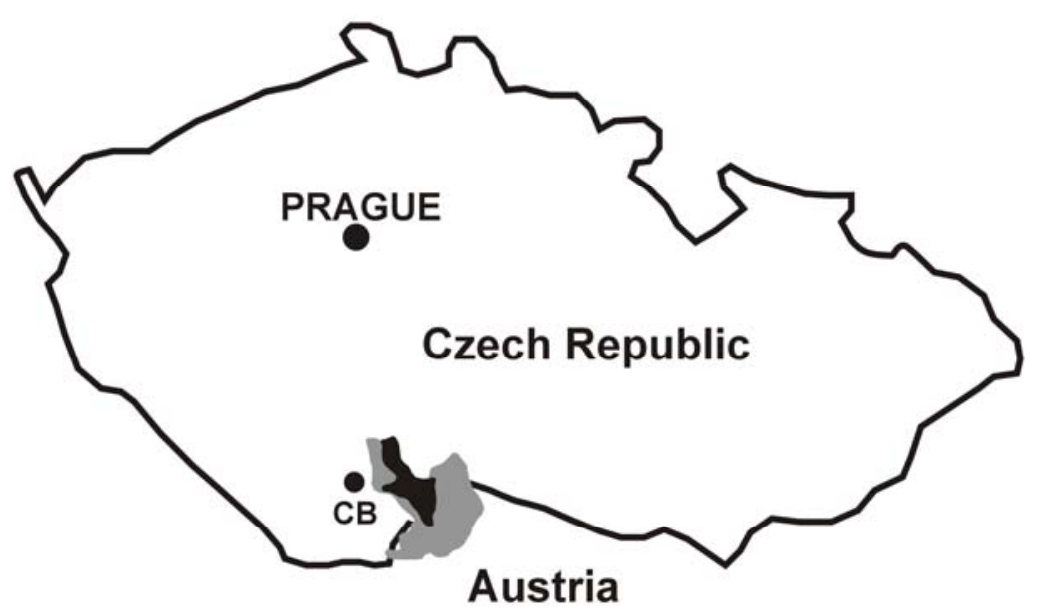

Fig. 1. Situation of the Lužnice River basin with basin outlet in Veselí nad Lužnicí (grey) and of the Třeboň fishpond system (black) on the map of the Czech Republic 


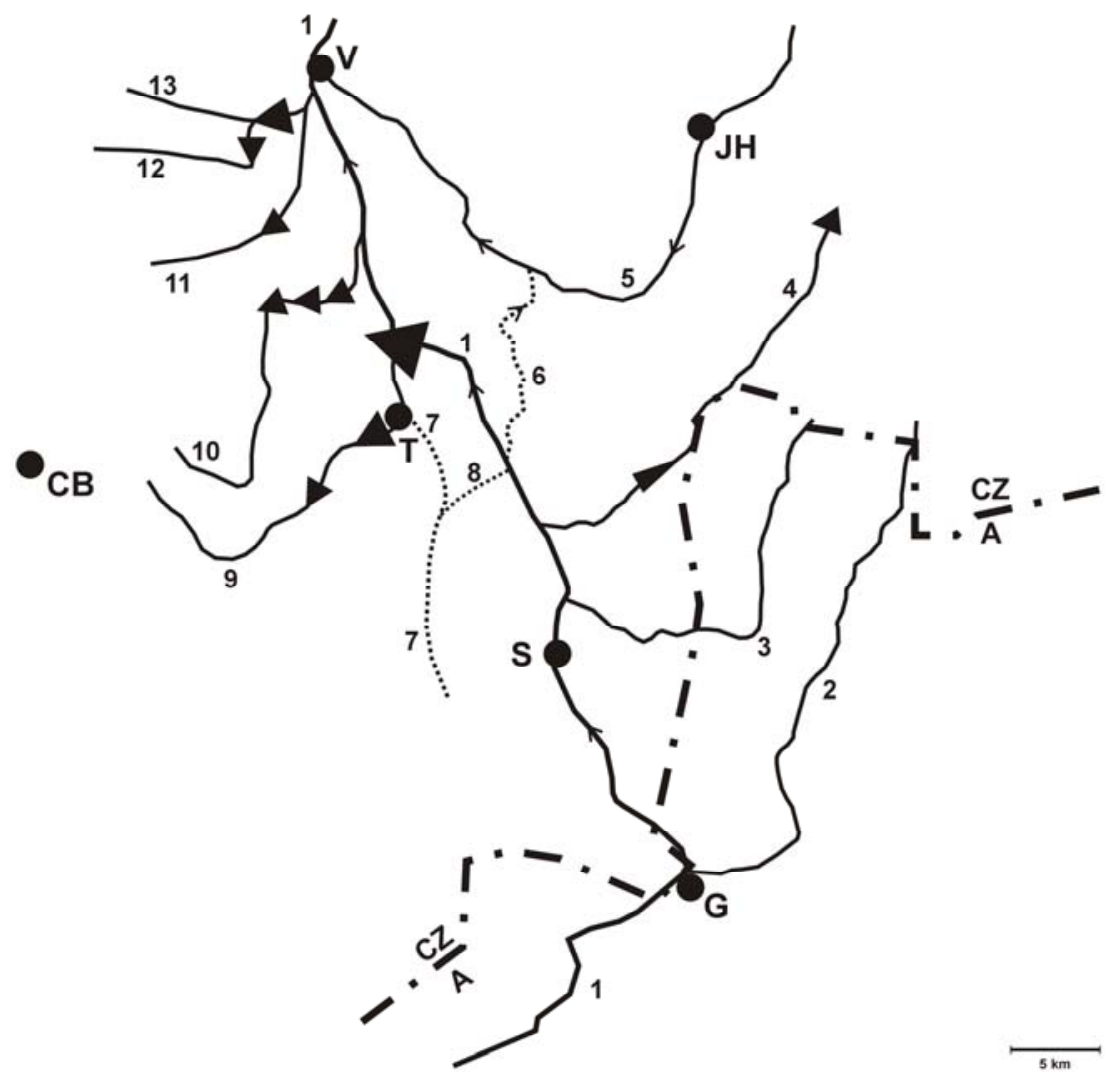

Fig. 2. Scheme of the Třeboň fishpond system; $-\cdot-\cdot--$ national boarder, $\mathrm{CZ}-\mathrm{Czech}$ Republic,

A - Austria; towns: CB - České Budějovice, JH - Jindřichův Hradec, G - Gmünd (Austria),

S - Suchdol nad Lužnicí, T - Třeboň, V - Veselí nad Lužnicí; streams: 1 - Lužnice,

2 - Braunaubach, 3 - Dračice, 4 - Koštěnický potok, 5 - Nežárka, 6 - Nová řeka (the "New River", a man-made canal), 7 -Prostřední stoka (the Middle gutter, a man-made canal), 8 - Odlehčovač (the alleviating canal), 9 - Spolský creek, 10 - Miletínský creek, 11 - Dubenka, 12, 13 - tributaries of the Bošilecký and Horusický fishponds

which include also the basin of the Lužnice River. Other data have been collected from reports on physical damage and flood events of the national administrations of the Czech Republic, the integrated rescue system of the Czech Republic, municipalities, towns, district and Třeboň Fishery commissions for floods and from personal observations.

The water management relations were studied from manuscripts on water management written in the middle of the $20^{\text {th }}$ century by Jindřich Šiman. Jindriich Šiman worked as a water manager and described in detail large flood events of the years 1890 and 1925, both as an expert and as an eyewitness of the events (ŠIMAN, 1949; 1959). The personal observations were collected during flood events in 2002 and 2006. 


\section{THE SHORT HISTORY OF PONDS}

The most important characteristic of a fishpond is that it is possible to drain it completely and refill it with water again. Another important characteristic is a rather small average depth. Fishponds usually reach an average depth of $1 \mathrm{~m}$ although in individual cases they are deeper near the dam, sometimes reaching even more than $10 \mathrm{~m}$. Most of ponds are built in the valley parallel to the river bed, but there are some closing the river by earth dams (Fig. 3). There are still many ponds with wooden outlet pipes (Fig. 4), the larger fishponds are nowadays equipped with either steel pipes or concrete or stone channels. The outlets at smaller fishponds are typically single or double wooden monk outlets (Fig. 5) and at larger fishponds sluice gates with a steel plate.

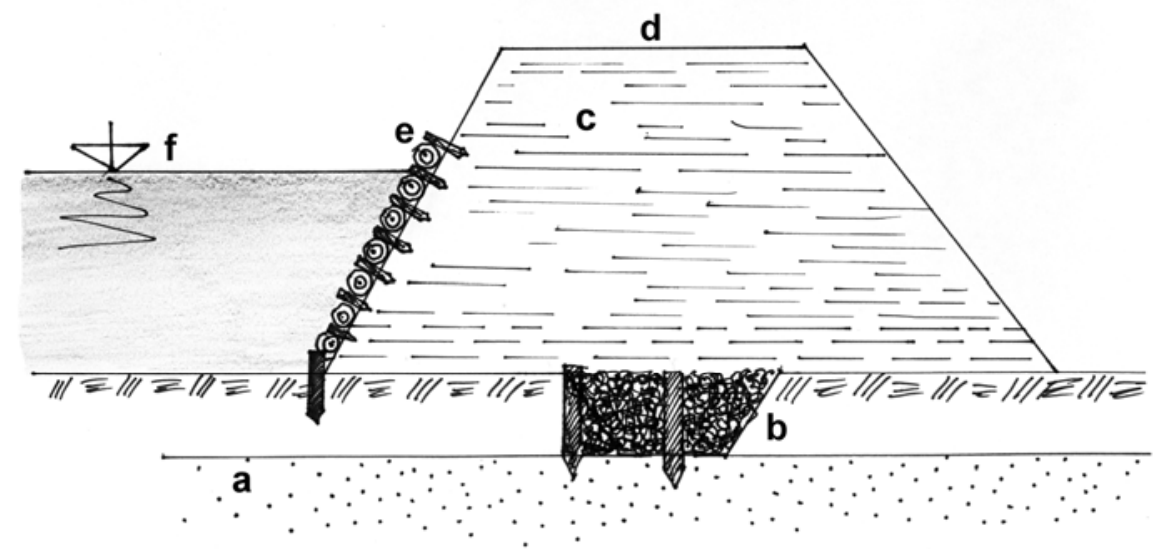

Fig. 3. Earthen dam; $a$-impermeable substratum, $b$ - trench filled with coarse material, $c$ - compacted earthen material, $d$ - dam crest, $e$ - wooden (later stone) riprap, $f$ - water level

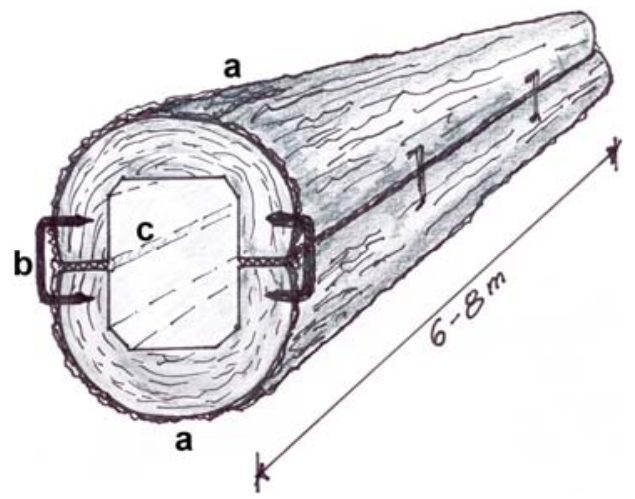

Fig. 4. Wooden outlet pipe; $a$ - two hewed trunks set together, $b$ - staple, $c$ - joints filled with moss 


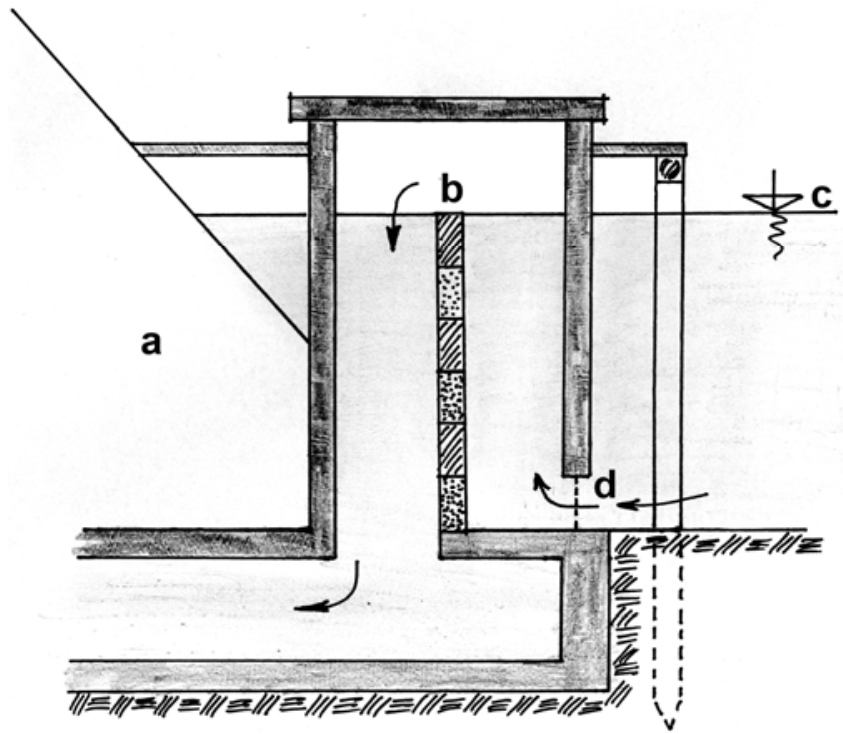

Fig. 5. Wooden monk outlet; $a$-dam, $b$ - boards, $c$ - water level, $d$-screen

Since the Middle Ages many ponds have been supplied with water through a system of water canals or gutters. The best known of these structures are the Opatovický canal in Eastern Bohemia (32 km, founded in 1530) and Zlatá stoka in Southern Bohemia (45 km, founded in 1520). A lot of ponds also have bypass canals which enable, if necessary, closing the water supply into the fishpond.

Ponds for fish production were built first around cloisters, which played an important role in land colonisation. It is assumed that monks acquired the skills needed for fishpond building during pilgrimages to Palestine. The new techniques of building ponds, such as dam rip-rapping, were also later brought to Europe from the Middle East by the German order of knighthood and by Templars returning from crusades.

The greatest boom of fishpond building occurred in Central Europe, in particular in Bohemia and Moravia, during $15^{\text {th }}$ and $16^{\text {th }}$ centuries when fish trade was one of the most profitable farming activities.

The number and surface area of fishponds have remained more or less the same since the beginning of the $19^{\text {th }}$ century until today. Intensification, however, has led to a significant increase in fish production (P ŘIKRYL, 2004) - Table 1.

Some fishponds played an important role in fortification of medieval towns, some were built for power generation for mills or mines and some were designed to retain water in case of flooding. It was for example the Staňkovský fishpond (Třeboň fishpond system, founded in 1556) with its $15 \mathrm{~m}$ high dam which was built for safety reasons. 
Table 1. Development of total fishpond area and total fish production in Bohemia and Moravia (PŘIKRYL, 2004)

\begin{tabular}{c|c|c}
\hline Period & $\begin{array}{c}\text { Area } \\
\text { thous. ha }\end{array}$ & $\begin{array}{c}\text { Fish production } \\
\mathrm{kg} \cdot \mathrm{ha}^{-1}\end{array}$ \\
\hline 14th cent. & 75 & 40 \\
16th cent. & 180 & 40 \\
18th cent. & 79 & 30 \\
1850 & 35 & 25 \\
1924 & 44 & 81 \\
1956 & 50 & 137 \\
1965 & 50 & 210 \\
1975 & 51 & 328 \\
1985 & 52 & 393 \\
1995 & 52 & 423 \\
\hline
\end{tabular}

Even today some ponds serve also functions other than fish production, primarily functions connected with water management during flood events.

Some of the ponds supply water for irrigation, serve for secondary treatment of drained water or for power generation. Some of ponds are used nowadays also for recreation, either for angling or for water sports. Unlike in the past times, one of the most important functions of fishponds today is their landscaping and biodiversification role.

\section{MORPHOLOGY AND HYDROLOGY OF THE TŘEBOŇ FISHPOND SYSTEM}

Because of its basin morphology with plentiful water supply Southern Bohemia has always been considered suitable for the development of fish farming. This holds true in particular for České Budějovice and Třeboň basins. The latter is very important also because it includes the largest fishpond Rožmberk of 500 ha water surface, which is situated right in the centre of the Třeboň basin. Most of the ponds of the Třebon̆ fishpond system lie within the Protected Landscape Area Třeboňsko, which protects this unique landscape that has been formed by man for centuries of cultural landscaping. The Protected Landscape Area Třeboňsko is simultaneously one of the six biosphere reserves in the Czech Republic. Moreover, the most valuable ponds and wetlands are protected under the Ramsar convention (site name: Třeboň fishponds).

Basic hydrologic parameters of the Třeboň pond system are shown in Table 2. It is somewhat difficult to define the area of the Třebon fishponds system. Whereas geographically it is easily defined by the Třeboň basin, from the hydrological point of view it is important to include the whole catchment of the Lužnice River from its spring in Novohradské Mountains, including the Austrian part of the catchment 
and catchments of all its tributaries. With the northern borderline delineated by the confluence of the Lužnice and Nežárka rivers, the Třeboň fishpond system has an area of $1700 \mathrm{~km}^{2}$ (Figs 1, 2).

Table 2. Basic hydrologic parameters of the main streams in the Třeboň fishpond system

\begin{tabular}{l|l|c|r|r|r|r|r}
\hline \multirow{2}{*}{ Stream } & \multirow{2}{*}{ Profile } & $\begin{array}{c}\text { Catchment area } \\
\mathrm{km}^{2}\end{array}$ & $Q_{1}$ & $Q_{5}$ & $Q_{10}$ & $Q_{50}$ & $Q_{100}$ \\
\cline { 4 - 8 } & & 268 & 17.0 & 35.0 & 50.0 & - & 110.0 \\
\hline Lužnice & Ehrendorf & 1567 & 16.0 & 34.0 & 48.0 & 106.0 & 145.0 \\
Lužnice & Frahelž & 153.0 & $\mathrm{~m}^{3} \cdot \mathrm{s}^{-1}$ & \\
Skřemelice & Hoheneich & 293 & 18.0 & 32.0 & 46.0 & - & 90.0 \\
Dračice & Klikov & 153 & 8.4 & 20.0 & 28.0 & 50.0 & 63.0 \\
Koštěnickýn & Chlum u T. & 169 & 5.0 & 13.0 & 18.0 & 32.0 & 40.0 \\
\hline
\end{tabular}

$Q_{N(1-100)}-N$-year (1-100) discharge - maximal discharge with a return period of $N$ years. Publicly accessible data provided by the Czech Hydrometeorological Institute and Povodí Vltavy.

The natural backbone of the whole area is the Lužnice River, which rises on the Austrian side of the Novohradské mountains. The most important Austrian tributary of the Lužnice River is a small river Braunaubach. At the confluence with the Lužnice River the area of the Braunaubach catchment is $293 \mathrm{~km}^{2}$ (Lužnice 275 $\mathrm{km}^{2}$ ). The course of flood events of both rivers, or in other words the concurrence of flood wave culminations, is crucial for the course of the downstream flooding of the Lužnice River, in particular in the Novořecké splavy (New river weirs) area. There are many ponds in Braunaubach catchment, however, as their own catchments are small, their role in water retention during big flooding is negligible. The overall area of these fishponds is 400 ha with the normal volume estimated at $4.3 \mathrm{mln} \mathrm{m}^{3}$ (ŠIMAN, 1959).

The next major tributary, the Dračice River, is situated already in the Czech Republic (catchment area $-155 \mathrm{~km}^{2}$ ). Like the Braunaubach, the Dračice River has also an important effect on the course of flooding in the Lužnice River. The flood wave, however, may be partly regulated in several flow-through fishponds both in the Czech Republic and in Austria (Herrenteich and Schönauerteich). The overall area of these fishponds is 279 ha with the volume estimated at $3 \mathrm{mln} \mathrm{m}^{3}$ (ŠIMAN, 1959).

The third main tributary of the Lužnice River before the profile of Novořecké splavy is the Koštěnický Creek. There are three ponds within its catchment: Kačležský (197 ha), Staňkovský (276 ha) and Hejtman (80 ha). It is the Staňkovský pond which has an important role in water retention. Its retention volume is set by the operational guidelines to $2.4 \mathrm{mln} \mathrm{m}^{3}$.

One of the most important water structures of the Třeboň fishpond system is the canal „New River“. This man-made canal (finished in 1590) diverts part of the water of the Lužnice River to the Nežárka River. Three side weirs serve for water 
regulation in the Lužnice River in the place of Novořecké splavy. According to the existing needs the side weirs conduct water either to the original river bed (the „Old River“, the Lužnice River itself) or to the man-made canal of the „New River". Weirs also protect the dike, which forms the first $6.5 \mathrm{~km}$ of the left bank of the New River. The material used for construction of the dike is of bad quality, soft and with permeability coefficient $K=10^{-2}$ to $10^{-3} \mathrm{~cm} \cdot \mathrm{s}^{-1}$ (ŠVARC, 1995). This is why the dike of the New River was largely damaged during most of the big flood events. It was already in 1586 during the time of its construction when the weirs on this dike were taken down by spring waters. Twenty seven metres of the dike were destroyed in the year 1670. In 1730 it was burst open at two sites, in 1804 even at five sites while the longest bank ripping was $72 \mathrm{~m}$ long. During the flooding of 1890 the dike was burst open at four sites and it was completely destroyed down to the impermeable subsoil. Subsequently the dike was repaired in 1891. The next reconstruction was not done until 100 years later. The first phase of repairs began in 1992 (ŠVARC, 1995). The dike was again largely damaged during the flood event in 2002 even though $70 \mathrm{~m}$ of the dike were cut through to prevent vast damage. Also the spring flooding in 2006 damaged the dike, in particular by many seepages.

On the New River weirs, water is regulated in compliance with the operational guidelines, however, when there is no flood discharge the flow in the Old River is regulated with respect to the management of the Rožmberk fishpond. During flood discharge the flow rates $Q$ are maintained at $Q=6 \mathrm{~m}^{3} \cdot \mathrm{s}^{-1}$ for the Old River and at $Q=50 \mathrm{~m}^{3} \cdot \mathrm{s}^{-1}$ for the New River. If the flow rate of the Lužnice River is higher than $56 \mathrm{~m}^{3} \cdot \mathrm{s}^{-1}$, the flow rate in the New River is maintained at $Q=50 \mathrm{~m}^{3} \cdot \mathrm{s}^{-1}$ by opening the weirs and diverting water to the Old River. By maintaining the water surface approximately $1 \mathrm{~m}$ below the dike crest, this process helps to stabilize the dike. Whereas the left bank of the New River is protected by the dike, the right one is opened to wide meadows and marshes (ca. 250 ha). This vast area retains large amounts of water during flooding (estimated retention volume of $4 \mathrm{mln} \mathrm{m}^{3}$ ) which usually prevents the flood waves of the New and the Nežárka rivers from culminating simultaneously. However, when a flood event is exceptionally high and there is co-culmination of the flood waves of the New and the Nežárka rivers, the towns downstream of the Lužnice River (Veselí n. L., Soběslav) are often seriously affected.

The Rožmberk pond holds water coming not only from the Lužnice River catchment (reduced by the New River outflow) but also from the catchment of the so called „Middle gutter“ $\left(223 \mathrm{~km}^{2}\right)$ which drains among others also the Spolský Creek and the Cep fishpond catchments, which are very rich in precipitation. The dam thus closes up the catchment of an area of $1397 \mathrm{~km}^{2}$.

The Spolský Creek $\left(85 \mathrm{~km}^{2}\right)$ and its tributaries rise in the south-east of České Budějovice in an area which has always been characterized by abrupt and heavy rains. The long-term mean annual precipitation in this catchment is $680 \mathrm{~mm}$. The 
watershed outlet of this catchment is the Svět fishpond (215 ha) in the close vicinity of the town of Třeboň. To mitigate the impacts of large flood events on Svět's dam (which was not equipped with the overflow spillway until 2002), the designer of this pond, Jakub Krčín, built in mid $16^{\text {th }}$ century another pond, called Spolský (137 ha), above the Svět pond. The Spolský pond thus served as a reservoir for water retention. It was the ponds on the Spolský creek which were hit by the most devastating floods as will be shown later. Before reaching Rožmberk the outflow of the Svět fishpond joins with the Middle gutter, which drains a vast area of forested peatlands. Although the retention capacity of the sensitively drained peatlands is high, the spring waters of the Middle gutter overflow yearly the suburb areas of Třeboň and show clearly why the meadows of many hundreds of hectars east of Třeboň are called Wet Meadows. In the 1970s a canal was built connecting the mentioned peatland area with the Lužnice River. If the bed of this Alleviating canal (Odlehčovač) is clean, it can reduce the water supply to Třeboň and the Rožmberk fishpond by as much as $10 \mathrm{~m}^{3} \cdot \mathrm{s}^{-1}$.

Water from the Rožmberk pond $\left(6 \mathrm{~m}^{3} \cdot \mathrm{s}^{-1}\right)$ is used also for power generation. Its water supplies the downstream situated ponds and fish storage ponds and maintain the minimum flow in the Lužnice River $\left(650 \mathrm{dm}^{3} \cdot \mathrm{s}^{-1}\right)$. The controlled retention volume of $9 \mathrm{mln} \mathrm{m}^{3}$ is delineated by the height of storage volume and the height of normal volume (spillway crest height). However, the largest flood events in the last centuries exceeded the spillway crest height often by more than $1 \mathrm{~m}$.

\section{SOME REMARKS ON PONDS MANAGEMENT}

Under normal conditions the regulation of water table depends on local fish breeding plans and must comply with the operational guidelines of every pond. The real height of water table in the fishpond may fluctuate throughout the year according to the needs of fish production. The normal height is set by the water management authorities. It commonly equals the spillway crest height, if the pond has a spilway. The water level in ponds of special importance for water management is lower than the normal height. The obtained volume represents a controlled retention volume. The obligation of the owners to maintain the normal height was set in the Mill Regulation as early as in 1814 although the normal level marks were not installed until 1870. In spite of this it has always been disputed whether this or that fishpond is filled up to the right height and would not flood the surrounding land. Before the Second World War the owner of the flooded land had the right to seek compensation if it was proven that the fishpond owner failed to open the outflow when water had risen above the normal height.

Setting the maximum height of water surface and thus the uncontrolled retention volume of the fishpond is a complicated task. For the purpose of calculations the maximum height reached in the fishpond was used, i.e. usually the height dur- 
ing flood in 1890. The maxima reached during flood in 2002 were in many cases higher than those during the 1890 flood and therefore, in the new operational guidelines the lowest height of a dam crest is set as the upper level of the uncontrolled retention volume.

It holds true that the weakest link in the chain determines the strength of the whole system. The ponds with their origin in the $16^{\text {th }}$ century have a lot of these weak links.

The majority of ponds in the Třeboň area have a homogenous earth dam which was built from locally accessible material, often of rather low quality. Therefore, the intense flood events often cause dam seepage.

To prevent dam from overflowing it is useful, in some cases, to break the dam through. It must be done only on the end of the dam or on side dams. It protects the surrounding land and prevents from uncontrolled damage of the fishpond. This precaution was taken for example in 1890 on the Svět fishpond's dam and later in 2006 on the side dam of the Staňkovský fishpond in order to use the retention volume of the neighbouring Špačkov fishpond. Under some circumstances, however, this precaution is inadequate to prevent large destructions as was obvious for example at the New River in 2002. Anyway, it is always true that any intervention into the main dam can lead to uncontrollable consequences.

Another weak link of a fishpond may be the outlet device. Although the original 450 years old outlet pipes have all been replaced, a lot of large fishponds still have wooden (fir, larch or exceptionally oak) pipes from the $19^{\text {th }}$ century. Construction of the outlet pipes sometimes caused a wash out of material from the body of the dam where the outlet had been constructed. This led to the creation of a cavern in the body of the dam. A cavern of $5 \mathrm{~m}$ in diameter appeared by one of the outlets of the Rožmberk fishpond in 1915. A smaller cavern appeared also during the flood in 2002 in the Podřezaný fishpond in the Cep catchment of a great importance for water retention. Also the outlet devices themselves can fail in the most critical moments. The rusty plate stuck in the second gate of the Svět fishpond in 2002 provided tangible evidence that the water management structures had often not been properly maintained.

Not all of the fishponds are equipped with an overflow spillway for taking away the excess water. But problems occurred even in fishponds where there are overflow spillways. The spillways were often overgrown by vegetation, they are used for other purposes or racks are not properly maintained.

The spillway of the Svět fishpond has had an interesting history. Its construction project was submitted in 1891. It was planned as a spillway with gates, which were opened only in emergency. The owners of the surrounding land (meadows), in particular from Třeboň, who were threatened by the overflow challenged this project. In 1894 the project was withdrawn. A make-shift solution was found in 1930 when large outlets were built which, however, discharged water to a too small outlet drainage canal. It was the large flooding in 2002 which finally led to the 
construction of an emergency spillway which was later rebuilt into a permanent overflow spillway.

The state of the water management structures on fishponds has significantly improved after the flooding in 2002. A lot of fishponds have been equipped with new overflow spillways.

Table 3 shows the different types of damages on fishponds within the Třebon̆ fishpond system (TRS) in 2002 related to the total fishpond damages. Similar data are presented for the whole of the Czech Republic (data provided by the Ministry of Agriculture of the Czech Republic).

Table 3. Fishpond damages during the 2002 flood

\begin{tabular}{l|c|c}
\hline \multicolumn{1}{c}{ Damage } & TFS, \% & ČR, \% \\
\hline Crack - outflow & 5.7 & 2.8 \\
Dam damage due to a displaced trees & 8.6 & 3.2 \\
Crest damage caused by overflow & 37.1 & 12.4 \\
Dam seepage & 5.7 & 6.1 \\
Outlet destruction or damage & 22.9 & 13.6 \\
Overflow spillway destruction or damage & 28.5 & 19.7 \\
\hline
\end{tabular}

TFS - Třeboň Fishpond system, ČR - Czech Republic.

\section{RETENTION IN THE CATCHMENT OF THE LUŽNICE RIVER}

With respect to the retention function of the ponds, the Třeboň area can be divided by the dam of the Rožmberk pond into two parts. The first part spans from the springs of the Lužnice River to the dam and the second part spans from the dam to the confluence with the Nežárka River. In the first area of $1397 \mathrm{~km}^{2}$ there are about 800 fishponds with cadastral area of 5585 ha and retention volume of at least $52 \mathrm{mln} \mathrm{m}$. The mean retention capacity of $1 \mathrm{~km}^{2}$ of this catchment is about 37000 $\mathrm{m}^{3}$. The hydrological relations of this area are very complex as the conseqences of flood events depend both on the flows in tributaries of the Lužnice River coming from the Českomoravská Vysočina highlands and water management practices. The retention capacity of ponds in the regions around Jindřichův Hradec and Dačice, which influence the Třeboň basin, was estimated by ŠIMAN (1959) to be approximately $3.5 \mathrm{mln} \mathrm{m}^{3}$. The retention capacity of pond systems in the Lužnice River catchment in Austria is approximately $2.5 \mathrm{mln} \mathrm{m}^{3}$. The catchment of the Lužnice River is able to retain around $7 \mathrm{mln} \mathrm{m}^{3}$ of water before the streams reach the Czech Republic. With respect to flooding in the Czech Republic it is clear that the water retention of the catchment on the Austrian territory is insignificant mostly due to the character of the upstream part of the catchment, which is steep and where there are only small reservoirs whose retention capacity is very limited. 
Consequently, it is the reservoirs of the Třebon̆ region that can provide large retention volumes.

A flood wave is extensively transformed by the Staňkovský fishpond. A flood wave with culmination $Q_{100}=44 \mathrm{~m}^{3} \cdot \mathrm{s}^{-1}$ is in this fishpond transformed to $Q_{O}{ }^{\mathrm{TR}}=$ $12.60-17.07 \mathrm{~m}^{3} \cdot \mathrm{s}^{-1}$ depending on the chosen type of regulation. The New River and its weirs play important role in flood wave transformation as do the key fishponds Spolský and Svět which transform the flood wave in the dangerous Spolský Creek. The Spolský fishpond transforms the flood wave from $Q_{100}=45 \mathrm{~m}^{3} \cdot \mathrm{s}^{-1}$ to transformed outflow $Q_{O}^{\mathrm{TR}}=13 \mathrm{~m}^{3} \cdot \mathrm{s}^{-1}$ whereas the Svět fishpond transforms the flood wave from $Q_{100}=36 \mathrm{~m}^{3} \cdot \mathrm{s}^{-1}$ to $Q_{O}{ }^{\mathrm{TR}}=9.75-3.32 \mathrm{~m}^{3} \cdot \mathrm{s}^{-1}$ depending on the chosen regulation and the use of a spillway. The controlled retention volume of 9.1 $\mathrm{mln} \mathrm{m}^{3}$ makes the Rožmberk pond the most important reservoir in this area. During the flooding in 2002 the Rožmberk pond retained about $50-60 \mathrm{mln} \mathrm{m}^{3}$ of water, when the estimated inflow to the fishpond was $540 \mathrm{~m}^{3} \cdot \mathrm{s}^{-1}$ after the New River dike and sand pit Cep had been broken,.

A rather large retention function may be fulfilled by the vast areas of sensibly drained peatlands in the Southern part of the Třebon region unless it is in the interest of nature protection to maintain permanently high ground water level there. If the ground water level were lowered to minus $60 \mathrm{~cm}$ below ground, an estimated retention volume of $5 \mathrm{mln} \mathrm{m}^{3}$ would be created. Also the alluvial plain of the Lužnice River near the national border (Suchdol n.L.) which is no more used for farming and marshes around the New River may be included into water retention capacity calculations. The estimated retention volumes of the former and the latter were $9 \mathrm{mln} \mathrm{m}^{3}$ (in 2002) and $4 \mathrm{mln} \mathrm{m}^{3}$, respectively (PITHART et al., 2008).

The second area of a great importance in terms of water retention of the Lužnice River is between the Rožmberk fishpond's dam and the conflunce of the Lužnice and Nežárka rivers. There is about 190 fishponds in this area of $387 \mathrm{~km}^{2}$ with the cadastral area of 3600 ha and retention volume of at least $24 \mathrm{mln} \mathrm{m}^{3}$. The mean retention capacity of $1 \mathrm{~km}^{2}$ of this catchment is thus about $62000 \mathrm{~m}^{3}$. Consequently, the retention capacity of this region is almost twice as high as the retention capacity of the upstream Lužnice River. Moreover, the hydrological relations of this region are less complicated. On the other hand, the region is intensely used for farming and the farming activities may influence the retention capacity of the landscape. There are also several pond systems with large retention volume in this region.

Also the Miletínský Creek, rising east of České Budějovice, is an important stream. The Vlkovický, Dvořiště, Koclírov and Velký Tisý ponds are situated directly on this stream. Their overall retention capacity was estimated at $12.6 \mathrm{mln} \mathrm{m}$ after floodings in 1890, 1915 and 1925. In 2002 these ponds retained $13.8 \mathrm{mln} \mathrm{m}$ of water.

Another interesting area is the catchment of the Dubenka Creek, which rises near the Ševětín village. An important hydrological part of this catchment is the 
Záblatský fishpond. The estimate of its total safety volume was originaly set to $2.08 \mathrm{mln} \mathrm{m}^{3}$. However, after the 2002 flood the estimate had to be corrected to 2.2 $\mathrm{mln} \mathrm{m}^{3}$.

The last ponds of major importance for water retention in the Lužnice catchment are the Bošilecký and Horusický fishponds. They close up a catchment of 68

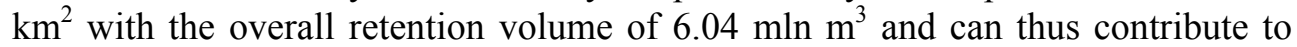
reduction of the flood wave culmination at the confluence of the Lužnice and Nežárka rivers.

ŠIMAN (1959) stated that the whole Lužnice catchment includes 984 fishponds with the overall cadastral area of 9194 ha and the retention volume of $76 \mathrm{mln} \mathrm{m}^{3}$. At the confluence with the Nežárka River the long term mean annual flow rate of the Lužnice River is $4.92 \mathrm{~m}^{3} \cdot \mathrm{s}^{-1}$. Consequently the Třeboň fishpond system and the connected subcatchments in Austria and the Czech Republic can retain 50\% of the mean annual runoff of the Lužnice River. From the records of the water surface heigths during water culmination in the course of the 2002 flood event it is possible to estimate the flood event retention of the Třeboň fishpond system at $110-140 \mathrm{mln}$ $\mathrm{m}^{3}$. Assuming that the long term mean annual flow rate of the Lužnice River is $4.92 \mathrm{~m}^{3} \cdot \mathrm{s}^{-1}$, this volume represents $70-90 \%$ of the mean total annual runoff.

\section{IMPORTANT FLOOD EVENTS IN THE AREA}

In 1890 there was a large flood caused by a meteorological situation similar to that in 2002. Within the Spolský Creek catchment, the precipitation was $130 \mathrm{~mm}$ during 92 hours. The total runoff was estimated at $7.1 \mathrm{mln} \mathrm{m}^{3}$ with the runoff coefficient of $64 \%$. As several fishponds situated at the Spolský Creek and subsequently also the Svět pond burst open, the course of the flood event near Třeboň was very dramatic and finally the surroundings of Třebon were flooded. A weak link of the chain was the 0.62 ha large Slavíček pond which had been in bad shape. The dam, not maintained for a long time, could not sustain the overflow of water. The dam of the Lazna pond, the next in the fishponds system, was also not properly maintained and as a consequence of incorrect handling of gates the dam was not able to hold the $60000 \mathrm{~m}^{3}$ of water coming with the flash flood and burst opened. After the water destroyed or damaged the ponds situated downstream, its volume of $7.5 \mathrm{mln} \mathrm{m}^{3}$ hit the Svět pond's dam. The $2.5 \mathrm{~m}$ increase of water level could have been sustained by the Svět pond's dam, had it not been lowered near the brewery. The dam was lowered there to enable easier transport of ice from the fishpond to the cellars in the brewery. It was there that the dam was spilled over and burst open. The embankment of the Franz Josef railway to Vienna behind Třeboň could not stop the water anymore and the flood rushed through the „Wet Meadows" to the Rožmberk pond which was also in a critical situation. The damaged New River dike let the water flow back to the "Old" Lužnice River and consequently to 
Rožmberk fishpond. The total water volume in the fishpond was at that moment $47.5 \mathrm{mln} \mathrm{m}$. The flow rate at the overflow spillway was $200 \mathrm{~m}^{3} \cdot \mathrm{s}^{-1}$.

The flood in 1925 was caused by a local summer rainstorm in the Svět fishpond catchment. The mean rainfall in the catchment was $115.5 \mathrm{~mm}$ with a maximum of $150 \mathrm{~mm}$ during 12 hours. The total runoff from the catchment was 8.29 $\mathrm{mln} \mathrm{m}^{3}$, with the $84 \%$ runoff coefficient. Ponds in the catchment sustained the power of the floods, but newly reconstructed spillways spilled away large amounts of water. Svět pond which was not equipped with an overflow spillway was the weakest link during this flood. The inflow from the Spolský fishpond filled the Svět fishpond to the level of $50 \mathrm{~cm}$ below the dam crest, however, strong waves posed the danger of dam overspilling. The newly reconstructed spillway of the Spolský fishpond was therefore blanked off and the outflow from this fishpond was downregulated.

In comparison to other regions in the Czech Republic, during the 2002 flood the Třeboň region did not suffer so many tragic events. However, even in this region the damage to property, including fishponds, was large. Seventy ponds owned by the Třeboñ Fishery, the largest owner of the fishponds in the area, were damaged. The weak links of many water structures were identified during this flood event in many places, in particular in the improperly maintained water management structures (broken outflows, spillways, overgrown dams etc.). In spite of this, the Třeboň fishpond system retained an unbelievable amount, approximately 110$140 \mathrm{mln} \mathrm{m}^{3}$ of water. If we add to the fishponds' retention volume also the retention capacity of the landscape in the Třeboň region we see that the total retention volume of the catchment was more than $200 \mathrm{mln} \mathrm{m}^{3}$, which delayed the culmination of the flood wave in the Lužnice River by more than 60 hours (CHMI, 2003). Assuming that the fishponds retained $110 \mathrm{mln} \mathrm{m}^{3}$ of water during flood event, with the water depth of $2 \mathrm{~m}$, we would need to built a reservoir of 5500 ha to retain the same amount of water. The Třebon fishpond system is often compared with the dam reservoirs on the Vltava River. In 2002 Lipno, Rímov and Orlík dam reservoirs retained $220 \mathrm{mln} \mathrm{m}$ of water, although their retention volume is $76 \mathrm{mln} \mathrm{m}$ (data provided by the state enterprise Povodí Vltavy).

During the spring flood of 2006 available retention volume of the ponds in the Třeboň fishpond system was $22.32 \mathrm{mln} \mathrm{m}^{3}$. In several cases, however, water did not reach the fish management level. The real retention of the fishponds with volume $>1000000 \mathrm{~m}^{3}$ was estimated by the Třeboň Fishery staff to be $47.96 \mathrm{mln} \mathrm{m}$ during the culmination of the flood in the Rožmberk fishpond. The retention of the whole pond system was approximately by about $20 \%$ higher as the smaller ponds also contributed to the water retention and in some of these ponds, e.g. the Staňkovský pond, the maximum water level was reached later than in the Rožmberk pond. To improve the retention capacity of the Staňkovský pond the retention capacity of the neighbouring pond Špačkov was used by cutting through the side 
dam. The retention capacity of this subcatchment was also improved by sensible water regulation. The water was not allowed to flow through the Kačležský fishpond in the upper part of the catchment. The retention volume of this fishpond of more than $1 \mathrm{mln} \mathrm{m}^{3}$ was used in full and thus the Staňkovský fishpond was better prepared for the flood wave from the subcatchment. The total retention volume during the spring flood of 2006 of the fishponds outside the Třebon fishpond system (already mentioned Braunaubach, Dračice and Koštěnický creeks catchments still affecting the region) reached $4.02 \mathrm{mln}^{3}$ (data provided by Kardašova Řečice Fishery).

\section{CONCLUSIONS}

The retention volume of all fishponds in the Třeboň region is about $50-60 \mathrm{mln}$ $\mathrm{m}^{3}$ of water. The real volume of water retained in the fishponds in 2002 flood was approximately $120 \mathrm{mln} \mathrm{m}^{3}$. This was, however, an uncontrolable state when many dams were overspilled.

A lot of ponds are not equipped with devices for safe spilling over large amounts of water. The examples from the past show that large damage was often caused when small fishponds burst open (e.g. the 0.62 ha large pond Slavíček). The earthen dams are often built of material of low quality (the New River dike). Some outlet devices are wooden.

Water management of fishponds is in complience with the operational guidelines. Other ways of regulating may lead to financial losses for the pond owners with respect to fish production.

The retention capacity of the landscape has to be added to the retention volume of the fishponds. The retention volume of the landscape of the Třeboñ region has been estimated at more than $200 \mathrm{mln} \mathrm{m}^{3}$ in 2002 .

Retention volume of river reservoirs is usually smaller than their storage volume, whereas retention volume of ponds is mostly larger than their water storage volume. This ratio is determined by morphology of a given water reservoirs. River reservoirs are constructed for storage of large water volume (e.g. for energy production). They are mostly situated in deep river valleys, where relatively short dam stores large water volume. Ponds are mostly situated in plains or basins, they are shallow and their dams are long with relatively high freeboard (comparing to the depth of water) available for water retention. During flood events in pond areas, water spills into surrounding landscape mostly rich in wetlands or meadows and flood does not cause severe damages.

Whereas the older papers about water management reported on good coordination between agiculture, forestry and fish husbandry, the reports written after the World War II expressed the fear of possible conflict of interest. These fears were justified during the flooding in 2002. 
Comprehensive operational guidelines for the whole Třeboň region are important from the water management point of view.

If vegetation in the flooded areas tolerate and survive the flooding, the extent of damage is usually minor. The areas which sustain flooding can therefore be used for special forestry or farming.

A fishpond is a water management structure with many functions sensitively set into the landscape which we may call cultural landsape. If there is no fish production the pond becomes clogged and destroyed during several decades. In view of the extensive fish production it is worth trying to optimize the food chain in the fishpond and support the fish searching the natural food in order to maintain or improve the biodiversity of the ecosystem.

\section{Aknowledgement}

Let me thank Mr. Kačány, who participated in many landscaping activities in the 1980s, Mr. Hule, a prominent authority on the history of fishponds, Mr. Kubů, former director of the Třeboň Fishery, who kindly provided me with manuscripts by Jindřich Šiman and other valuable information, and Mr. Šedivý, who is the chief engineer responsible for water management of the Třeboň Fishery.

The work was supported by the project MSM 2B20623.

\section{REFERENCES}

1. Czech Hydrometeorological Institute: http://www.chmi.cz

2. Povodí Vltavy web pages: http://www.pvl.cz

3. Pithart D., KŘovÁKOvÁ K., DuŠEK J., ŽAloudíK J., 2008. Case study: Ecosystem services of a floodplain with a preserved hydrological regime, Czech Republic. In: The role of environmental management and eco-engineering in disaster risk reduction and climate change adaptation. Ed. N. Saalismaa et al. Geneva, ProactNet: 34-36.

4. PŘIKRYL I., 2004. Historický vývoj našeho rybníkářství a rybničních ekosystémů. Veronica 1: 7-10.

5. ŠIMAN J., 1949. Vodohospodářský průzkum soudního okresu třeboňského se zvláštním zřetelem na Vitorazsko. Třeboň.

6. ŠIMAN J., 1959. Vodohospodářský plán třeboňského okresu. Okresní plánovací komise. Třeboň.

7. ŠUSTA J., 1997. Výživa kapra a jeho družiny rybničné. Carpio, Třeboň

8. ŠvarC J., 1995. Oprava novořecké hráze. Vodní hospodářství, 10: 1-300.

9. TEPLÝ F., 1937. Př́spěvky k dějinám českého rybníkářství. Praha. 


\section{STRESZCZENIE}

\section{Funkcje starych stawów rybnych podczas występowania przepływów powodziowych}

Słowa kluczowe: hydrologia, ochrona przeciwpowodziowa, stawy rybne, zasoby wodne, zbiorniki wodne

Stawy rybne, szczególnie hodowlane karpiowe, oddziałują na reżim hydrologiczny rzek. Największy pobór wody ma miejsce w okresie wiosennym, zwykle w warunkach wysokich przepływów, natomiast zrzut wody prowadzony jest w okresie jesiennym. Uważa się, że stawy rybne pełnią pozytywną rolę w obiegu wody w zlewni. Dotyczy to m.in. ich funkcji w ograniczaniu zagrożeń powodziowych dzięki retencjonowaniu wody w okresach występowania większych przepływów. Na terenie Czech, w niektórych regionach, gospodarka stawowa jest bardzo rozwinięta. W wielu zlewniach zbudowano stawy o dużej powierzchni i dużej objętości retencjonowanej wody. Są to kompleksy stawów zbudowanych w dolinach rzecznych, do których woda doprowadzana jest w wyniku budowy jazu lub stopnia na rzece. Są to również zbiorniki powstałe na skutek przegrodzenia rzeki zaporą. Tworzą one wówczas tzw. stawy paciorkowe. Stawy rybne były budowane na terenie Czech oraz w innych krajach europejskich już w średniowieczu. W artykule przedstawiono krótką charakterystykę stawów rybnych wraz z ich historią oraz opisem starych rozwiązań konstrukcyjnych budowli piętrzących i upustowych. Szczególną uwagę zwrócono jednak na przedstawienie roli stawów w ograniczaniu zagrożeń powodziowych. Podane zostały przykłady ilości zretencjonowanej wody w okresach występowania przepływów powodziowych. Podawane są przykłady świadomego, częściowego opróżniania stawów w celu zwiększenia pojemności retencyjnej, aby przechwycić maksymalny przepływ w rzece.

Reviewers:

Dr Andrzej Lirski

Prof. Waldemar Mioduszewski 